«Keruen» scientific journal

M.O.Auezov Institute of Literature and Art

ISSN 2078-8134

Volume 2, Number 71 (2021)

https://doi.org/10.53871/2078-8134.2021.2-10

МРНТИ 17.07.65

UDC 821.161.1.0

\author{
O.A. Arukenova \\ Master of pedagogical sciences, $\mathrm{PhD}$ student in al-Farabi Kazakh National University \\ Kazakhstan, Almaty, \\ E-mail:arukenova@mail.ru \\ ORCID: 0000-0002-1402-8501
}

\title{
Colonial discourse in the novel of Chinghiz Aitmatov "White ship" expressed through dichotomy
}

\begin{abstract}
This article explores a novel of Chinghiz Aitmatov mostly famous under the title «White ship» regarding the semantic layers encoded in a dichotomy inherent in the mentality of Middle Asia ethnic groups. Texts created in Soviet times by representatives of Turkic culture on the border of a nomadic and sedentary lifestyle still need proper interpretation in terms of colonial discourse and a strategy for encoding meanings in the era of ideological censorship. The novel of Chinghiz Aitmatov has been analyzed in the article with use of literary psychoanalysis and intertextuality, the semantic layers of the work are considered in the aspect of ontological dichotomy. This paper traces how the author realizes his plan by contrasting mythological thinking and the colonial repressive system. The article reveals the function of the motive of fatherlessness and orphan hood, common in the works of Soviet authors and explores the role of the cruel state-superego-father, which destroy cultural identity and the spiritual origin of ethnos, replacing them with unification and facelessness. The mixture of subject and object, live and dead, past and future in the story form dichotomies of different levels and order, breaking the vacuum of the present: an orphaned boy without name, his grandfather as if from the mythological past, the white ship and a fairy tale without end.
\end{abstract}

Key words: dichotomy, colonial discourse, mythology, psychoanalysis, intertextuality, existentialism, fatherlessness, superego.

Introduction. The novel under consideration has been written by Chinghiz Aitmatov in 1970. Like many other works of the author, the novel has two titles: "The White ship" and "After the Tale". It's necessary to note that the title "After the Tale" is in the first place, but the readers remember the novel under "White Steamboat", and it had been repeatedly reprinted in Soviet times under this name and still being published in Russia.The variety of semantic layers is a characteristic feature of the works of many writers of the Soviet era, when the authors intuitively or intentionally applied such a strategy to adapt to the requirements of socialist realism.

The writers, representatives of the nomadic civilization of Central Asia mostly successfully expressed the key layers and meanings in their works through natural phenomena and images of totem animals, relying on ethnic plots and mythology. The motives of mixed Turkic-Persian folklore always fill the pieces of writing with mystical power and metaphor, which is also specific of the work of Chingiz Aitmatov. The anthropogenic myth of the deer-ancestress of the Kyrgyz tribe from the ancient Turkic folklore is one of the substantial layers of the novel. 
While in the foreground we see a white ship, which represents the modern world and European culture. It is evident that steamboat gives rise to many allusions from Marco Polo's travels to Alexander Greene's lyrics - a cultural layer laid down by the Eurocentric formation of the Soviet period. There was no place for the Arabian Renaissance, Farsi, and the history of nomadic tradition, ethnic mythology and the cultural and historical chronology of Turkic civilization, which formed the picture of the world of the nationalities of Central Asia.

There is a strong opinion in literary criticism that Chingiz Aitmatov was inspired by the works of Jack London, which is quite acceptable if it were not for the superficial European view of oriental culture, described so accurately by Edward Said [Said 1978]. As Castro-Gómez writes about colonial formation: «the coexistence of diverse ways of producing and transmitting knowledge being destroyed, since now all forms of human knowledge are ordered on an epistemological scale from traditional to modern, from barbarism to civilization, from community to individual, from East to West". According to the scientist, such a strategy allowed European scientific thought to win "epistemological superiority over all other cultures in the world" [CastroGómez 2007:433]. According to the words of another scientist in sphere of decolonization Madina Tlostanova: "the Western monopoly on the production and dissemination of knowledge and the disciplinary martice of modern/colonial knowledge remain unchanged today" [Tlostanova 2020].

Chinghiz Aitmatov begins the story with two titles and introduces us a short synopsis of two fairytales with a tragic final: "He had two tales. One of his own, and no one knew about it. The other one was told by the grandfather. Then not a single one remained. That's the point." [Aitmatov 2010:3].

Experiment. According to the dualistic drive theory of Sigmund Freud the drive to death in humans is opposed to the drive to live. "If we accept as an exception that the fact that all living being die due to internal causes, returns to inorganic, then we can say: the goal of all life is death, and vice versa - the inanimate was earlier than the living ..." [Freud 2007]. Erich Fromm, by extension of Freud's idea about the dichotomy of human being, noted: "Realizing himself, a man understands his powerlessness and the limitations of his existence ... He is never free from the dichotomy of his existence; he cannot get rid of his mind even if he wants to; he cannot get rid of the body while he is alive, but the body makes him want to live " But along with the existential contradictions of the human, the scientist distinguishes his reaction to historical contradictions. According to Fromm, a person can eliminate historical contradictions with his own activity, but is not able to eliminate existential contradictions. Thus, the scientist concludes that there is only one solution to the problem: to face the truth, to realize humans total loneliness and self-sufficiency in the universe indifferent to the fate of a person, to recognize that there is no power outside a person that can solve his problems for him [Fromm 2012: 6].

The boy from the story of Chingiz Aitmatov seeks his father on a white ship, but for this he needs to transform into a fish and swim to the white ship. "And then he will say to his father, the sailor:" Hello, dad, I am your son. I've come to you. " "What kind of son?" You are a half-fish halfman!" - "If you take me to your ship, and I will become your ordinary son." - "That's great! Well, let's try. Father will throw the net, catch the bay from the water, raise him to the deck. After that the boy will turn into himself. And then, then ... "[Aitmatov 2010: 15]. The boy had never seen his father therefore he had no idea about the relationship between father and son, so he could not imagine the rest. The transformation of the boy into a fish and crossing the river as a metaphor for death, formed in a scenario of a happy life with his father, is actually an ambivalent drive for life and death.

Existentialism as a philosophy is very close to the nomadic culture of Central Asia, since the dominant dichotomy of the region consists of a thousand-year history of the relationship between two opposing and at the same time interdependent groups: settled farmers who speak Farsi and Turkish-speaking nomads. The bilingual interaction of two cultures have favored openness and tolerance.

The law of eastern duality was preserved until the beginning of the 20th century and required the individual to be responsible for his choice, since the general culture of the region did not encourage 
ethnocentricity, as confirmed by written sources. With the colonization and establishment of Soviet power in Central Asia, instead of the usual eastern duality, a new type of dichotomy comes into the region: Eastern-European, expressed in pseudo-bilingualism with a privilege of the metropolis in the language and culture. If the relationship of the previous groups was based on the will and responsibility of the individual, then the colonial policy first brought with it the imperious, subjectobject nature of the relationship on the part of the metropolis, and then the Soviet government modified it into a totalitarian system, where a person is deprived of ethnic identity and freedom of expression. Despite this fact nationalities of Central Asia have preserved a centuries-old culture of duality. In the works of almost all the writers of Central Asia, both historical and existential duality are present. In the story of Chinghiz Aitmatov this tendency is fixed even at the level of the title of the work: "The White ship" and "After the Tale".

Results and discussion. Nobody calls the boy by name in the novel, he is an orphan with his living parents. His mother has left him with Grandfather Momyn and married again in the city, she has other children, new husband and family. The boy only knows about his father that he is a sailor, therefore the boy is so eager to reach the white ship and find there his imaginary father. All this happens in a culture where the succession of generations plays a major role in the upbringing of the children. Fatherlessness with a living father is a frequent character of the Soviet era, where the role of the father is given to the highest Super-ego - the state. This is a generation of children whose fathers died in World War II, children of repressed by Soviet regime and political prisoners. Most of them died in the prison or far from the family. But even with a living father, millions of Soviet children became a model of a system "without kith or kin" [Rancour-Laferriere 1980]. For example, in Andrei Bitov's novel "Pushkin's House", the role of the father had been completely given to Stalin, who physically, morally and spiritually destroyed the life and health of grandfather Odoevtsev, made a traitor out of Odoevtsev's son and a model convenient for the Soviet regime from his grandson, by breaking down the succession of the noble family. The fate of the boy from "White ship" is even more dramatic, no one calls him by name, and it is known that a person without name does not exist.

The only person who loves the boy is Grandfather Momun, an old man, good hearted weakling, who is called the deft Momun by people. Momun is translated from the Kyrgyz language as "meek". "Momun earned such a nickname by his invariable friendliness to all whom he knew even a little bit, his willingness always do something for anyone, to serve anyone. And yet his zeal was never appreciated by anyone, just as gold would not have been valued that had suddenly been given out for free. Nobody treated Momun with the respect that people of his age used to be treated... "[Aitmatov 2010: 27]. Old Momun is like archaism from the past, when people lived in harmony with nature and voluntarily served society and each other, since without this it was impossible to survive, hospitality and mutual assistance formed the basis of a nomadic lifestyle. Chinghiz Aitmatov is a master of shifters and multi-layered meanings and metaphors. In the story, the old man is depicted as a slave to his son-in-law, the cruel Orozkul, but in fact Orozkul is a slave, as his name is translated as "Oroz the slave." Orozkul is a slave and hostage to the totalitarian system, which has no future, because the sovereign of the cordon Orozkul cannot have physically children. The seer Chinghiz Aitmatov tells us that Orozkul and the power of the Soviet system are temporary. Orozkul is cruel, but his cruelty extends only to his closest people, his wife and fatherin-law.

The colonial system is built in such a way that it produces people who self-destruct and destroy their roots. And the regime's highest achievement is the killing of the deer ancestress by the hands of Grandfather Momun. Although the white ship symbolizes an unknown reality where the boy subconsciously aspires, it symbolizes also his future as it seems at first glance. But we perfectly know that the ship in art is one of the common metaphors of death. For example, Gustav von Aschenbach in Thomas Mann's novel "Death in Venice" floats in a boat through the Grand Canal, as if across the Styx River accompanied by his gloomy gondolier, the prototype of Charon [Mann 1992]. And the Egyptian god Osiris enters the kingdom of the dead on a lunar ship, sailing through the vast expanses of space. 
Conclusion. In Tenriism, as in many other archaic religions, death has a meaning of the transition or return to its element, so the death of the boy and his desire for water is not so tragic, it has the sign of liberation. Eastern dichotomy considers death as the end and a new beginning. Life after the tale continues entering into the outline of the tale invented by the boy. So we can state that "After the tale" is a real title and a message of the writer, while "White ship" is a look from another perspective.

According to the words of Lotman, in the clash of Western civilization with Eastern as a partner, civilizations retell unusual texts for themselves with the help of metalanguages of their own philosophy or science that is why they acquire the character of irrationality. The paradigm of the rational West and the irrational East arose consistently, irrational concepts were removed and confused from the western tradition, and rational grain, which had a strong place in it, was removed from the eastern tradition. At the same time, we can talk about the emergence of heterogeneous texts that arose from the combination of two cultural trends that form a multifaceted cultural continuum that can generate new texts for both traditions [Lotman 2010: 15]. Thus, the novel of Chingiz Aitmatov "After the Tale" is a vivid example of a creative writing with a multi-level historical and existential dichotomy that arose on the border of the paradigms of eastern and western civilization.

\author{
О.А. Арукенова \\ әл-Фараби атындағы Қазақ ұлттық университетінің PhD докторанты, педагогика \\ ғылымдарының магистірі, Қазақстан, Алматы, e-mail: arukenova@ mail.ru
}

\title{
Шыңғыс Айтматовтың “Ақ кеме” шығармасындағы дихотомия арқылы көрсетілген отарлық дискурс
}

Аңдатпа. Мақалада Шыңғыс Айтматовтың «Ақ кеме» шығармасы, Орта Азия халықтарының менталитетіне тән дихотомияларға енген семантикалық қабаттар тұрғысынан қарастырылады. Кеңес уақытында түркі мәдениетіне жататын жазушылардың көшпелі және отырықшы тұрмыс шекарасында жазылған мәтіңдері отарлық дискурс жағынан және идеологиялық цензура дәуіріндегі мағыналарды астарлау стратегиясына тиісті әлі де толық талданған емес. Мақалада «Ақ кеме» повесі әдебиеттанушылық психоаналитика және интертекстуалды әдістер арқылы қарастырылады, шығарманың семантикалық қабаттары онтологиялық дихотомия аспектісінде зерттеніледі. Мақалада, автор мифологиялық дүние тану мен отарлық жазалау жүйені қарама-қарсы қою арқылы өз ойын жүзеге асырады. Кеңес Одағында кең таралған әкесіздік пен жетімдік желісі және оның шығармадағы функциясы анықталады. Қатал мемлекет-әке-суперэгоның этностардың мәдені сәйкестік пен рухын жою оның орнына бірегейлендіру мен сүренсіздік орнату ролі зерттелінеді. Субьект пен объект, тірі және өлі, өткен шақ пен келер шақ повесте әр түрлі деңгейдегі дихотомия құрастырып осы шақтың вакуумын әшкерелейді: есімі жоқ жетім баланың атасы мифологиялық архаизм іспеттес болса ақ пароход туралы ертегінің басы бар аяғы жоқ.

Кілт сөздер: дихотомия, отарлық дискурс, мифология, психикалық талдау, интертекст, экзистенциализм, әкесіздік, суперэго.

\section{О.А. Арукенова,}

Магистр педагогических наук, докторантка Казахского национального университета им. аль-Фараби, Казахстан, г. Алматы, e-mail: arukenova@mail.ru 


\section{Колониальный дискурс в повести Чингиза Айтматова “Белый пароход" выраженный через дихотомию}

Аннотация: В статье анализируется повесть Чингиза Айтматова «Белый пароход» с точки зрения смысловых слоев, закодированных в дихотомии, свойственной ментальности народов Центральной Азии. Тексты созданные в Советское время писателямипредставителями тюркской культуры на границе кочевого и оседлого образа жизни все еще нуждаются в должной интерпретации в плане колониального дискурса и стратегии кодирования смыслов в эпоху идеологической цензуры. Повесть Чингиза Айтматова рассматривается в статье с точки зрения литературоведческой психоаналитики и интертекстуальности, смысловые пласты произведения анализируются в аспекте онтологичкой дихотомии. В статье прослеживается как автор реализует свой замысел через противопоставление мифологического мышления и колониальной репрессивной системы. В статье раскрывается функция мотива безотцовщины и сиротства, распространенного в произведениях Советских авторов. Исследуется роль жестокого государства-суперэго-отца, который уничтожая культурную идентичность и духовное начало этноса заменяет их на унификацию и безликость. Смешение субьектов и объектов, живого и мертвого, прошлого и будущего в повести образует дихотомии разного уровня и порядка, ракрывая вакуум настоящего: мальчик-сирота без имени при живых родителях, дед Момун словно из мифологического прошлого, белый пароход и начало сказки без финала.

Ключевые слова: дихотомия, колониальный дискурс, мифология, психоаналитика, интертекст, экзистенциализм, безотцовщина, суперэго.

Aitmatov.Ch. White ship. M.: ACT. 2010. P.352 (In Russian)

\section{REFERENCES}

Bitov A. Puskin's house.Novel. M.: ACT. 2010. P.464 (In Russian) (

Castro-Gómez S. The missing chapter of Empire: Postmodern reorganization of Coloniality and Post-Fordist Capitalism // Cultural Studies, 2007. \#21(2-3). P.428-448.

Lotman Y.M. Articles on semiotics and topology of culture. Tallin: «Alexandra» 2002. P. 32 (In Russian)

Mann T. Der Tod in Venedig. Novelle. Das Taschenbuchausgabe von Fischer.1992.

Rancour-Laferriere D. Semiotics, psychoanalysis, and science: Some selected intersections // Ars semeiotica. 1980. \# 3.

Said E.Orientalism. New York: Pantheon Books, 1978.

Tlostanova M. Post-Colonial Destiny and Decolonial Choice: postsocialist mediation // New literary review, 2020. \#161 (1/2020). P.66-85.

Freud Z. Introduction into psychoanalysis. 2007. [Electronic recourse].) - http://loveread.ec/view global.php?id=8775 (In Russian) Fromm E. Man for himself. Translated by A.B. Alexandrova. M.: Astrel. 2012. P.320 (In Russian) 